\title{
Kazım Karabekir Paşa: Kurtuluş Savaşı'nı ormanlar sayesinde kazandık
}

\author{
Erhan KILIÇ (Orcid: 0000-0002-3268-5038) ${ }^{1^{*}}$, Kenan OK(Orcid: 0000-0002-0292-6152) ${ }^{2}$ \\ 'Orman Genel Müdürlüğü, İstanbul Orman Bölge Müdürlüğ̈̈, İSTANBUL \\ ${ }^{2}$ İstanbul Üniversitesi, Orman Fakültesi, İSTANBUL \\ *Sorumlu yazar/Corresponding author: erhankilic@ogm.gov.tr, Geliş tarihi/Received: 16.05.2018, Kabul tarihi/Accepted: 27.05.2018
}

$\ddot{O} \mathbf{z}$

Kurtuluş Savaşı'nın kahraman komutanlarından Kazım Karabekir'in milli mücadeleye doğu cephesindeki katkıları ve kimsesiz çocukları himaye eden kişiliği bilinmektedir. Ancak, Kazım Karabekir'in ülke ormancılık eğitimiyle ilgisi, ormanlar ile milli mücadele arasında kurduğu ilişkiler yaygın bilinen konular değildir. Bu makalede, Kazım Karabekir'in 15 Kasım 1923’te Orman Mektebi Alisi'ne yapmış olduğu ziyarete yönelik tarihi belgeler tanıtılmakta, bu ziyaretten elde edilen bilgilerden günümüz için çıkarılabilecek sonuçlar tartışılmaktadır.

Anahtar Kelimeler: ormancılık tarihi, ormancılık eğitimi, Kazım Karabekir

\section{Kazım Karabekir Pasha: We won the independence war by the Agency of Forests}

\begin{abstract}
Kazım Karabekir, a hero commander of independence war of Turkey, is known with a great contribution at eastern front of the battle and personality to protect orphan children. However, Karabekir's interest in forestry education and ideas on the relations between forestry and independence war are not widely known. In this study, his visit to the Forest High School on November $15^{\text {th }}, 1923$ is presented and the documents and speeches deal with this event are investigated and discussed to understand forest history.
\end{abstract}

Keywords: forestry history, forestry education, Kazım Karabekir

To cite this article (Atıf): KILIÇ, E , OK, K . (2018). Kazım Karabekir Paşa: Kurtuluş Savaşı'nı ormanlar sayesinde kazandık. Ormancılık Araştırma Dergisi, 5 (2), 123-134.

DOI: https://doi.org/10.17568/ogmoad.424009

\section{Giriş}

Osmanlı İmparatorluğunda teknik ormancılık çalışmaları Tanzimat Fermanın yayımlanmasıyla birlikte başlamış olmakla beraber, 1857 yılına kadar istenilen seviyeye ulaşmamıştır. 1839 yılında bir Orman Müdürlüğü kurulmuşsa da, bu kurum 11 ay sonra kapatılmıştır (Gümüş, 2012). Bu kapatılmada, ormancılık çalışmalarında uzmanlaşmış insan kaynaklarının ülkede bulunmamasının şüphesiz etkisi olmuştur. Kırım Savaşı sonrasında getirilen Fransız uzmanların tavsiyesi doğrultusunda 1857 yılında ormancılık eğitimi başlamış, 1870 tarihli Orman Nizamnamesi ile en önemli hukuki düzenleme yapılmıştır.

1857 yılında açılan ve öğretim süresi 2 yıl olan okulda eğitim Fransız hocalar tarafından Fransızca olarak başlatılmıştır (Atay, 1975; Eraslan 1989). Bu okul, İstanbul'da yeri tespit edilemeyen eski Darphane binasında hizmet vermiştir. Okul, kurucusunun gayretlerine karşılık olarak, "Tassy Orman Mektebi” diye anılmıştır (Eraslan 1989; Gümüş, 2012).
Bir yandan ormancılık eğitim öğretim düzeni kurulmaya gayret edilirken diğer yandan kurumsallaşmaya çalışılmıştır. 1869 yılında Orman Müdürlüğü yeniden kurulmuş, özellikle 1870 tarihli Orman Nizamnamesi ile mülkiyet, kullanım hakkı, üretim ve satış gibi konularda kurumsal temeller atılmıştır.

Bütün bu çabalar içerisinde ormancılık eğitimi alanında istikrarlı bir yapının kolaylıkla kurulabildiğini söylemek güçtür. Nitekim Tassy’nin 1862 yılında ülkemizden ayrılması ile orman okulu kapatılmış, 1866 yılında dönmesiyle de yeniden açılmıştır (Gümüş, 2012). Tassy'den sonra bu okulun müdürlüğüne getirilen Simon, okul için 13 maddelik bir yönetmelik hazırlamıştır. 1869 yılında bu yönetmeliğin bir padişah oluru ile resmileşmesiyle birlikte, bünyesi, programı ve yönetim şekli resmen tanımlanmış ilk Orman Okulu ortaya çıkmıştır (Eraslan, 1989).

Ormancılık ve madencilik alanında faaliyet gösteren kurumların bir çatı altında toplanması yaklaşı- 
mı, ormancılık eğitim kurumlarını da etkilemişstir. 1880 yılında Orman Okulu ile Maden Okulu kald1rılarak 14 maddelik yeni bir yönetmelikle "Orman ve Maden Mektebi” kurulmuştur (Eraslan, 1989).

Yaklaşık 13 yıl faaliyet gösteren Orman ve Maden Mektebi'nden elverişli bir binanın sağlanamaması, yeni bir binanın yaptırılamaması, yeterli eğitim öğretim malzemesi ile kadroların sağlanamaması vb. nedenlerle (Eraslan, 1989) beklenen sonuçlar alınamamıştır. 1893 yılında maden bölümü kapat1lırken devletin yeni bir bina ve eğitim olanaklar1 sağlayabileceği zamana kadar, orman kısmının Halkalı Ziraat Mektebi Alisi'ne bağlanmasına karar verilmiştir.

$\mathrm{Bu}$ kararla birlikte ormancılık eğitim mekânı İstanbul'un batısında yer alan Halkalı'ya taşınmıştır. 1903 yılında alınan bir kararla ormancılık programının okul içerisindeki yeri biraz daha netleştirilmiş ve okul "Halkalı Ziraat ve Ormancılık Mektebi” adını almıştır (Eraslan, 1989).

Bir yandan Halkalı Ziraat ve Ormancilık Mektebi'nde, ormancılığın ihtiyaç duyduğu yükseköğrenim görmüş insan kaynağ1 yetiştirilirken diğer yandan daha iyi bir eğitim öğretim arayışları sürmüş ve bağımsız bir ormancılık okulunun daha etkin olacağ1 kanaati hâkim olmuştur. Bu anlayışla ve Hoca Ali Rıza Efendi'nin girişimleriyle bir yönetmelik hazırlanmış ve 1910 yılında kabul edilen bir padişah oluru ile "Orman Mektebi Alisi” kurulmuştur (Eraslan, 1989).

İkinci Meşrutiyet sonrası davet edilen Alman kökenli uzmanların katkılarıyla ormancılık çalışmalarının etkinliği artmıştır. Ormancılık alanında eksikliği şiddetle hissedilen nitelikli iş gücünü sağlamak üzere, var olan Orman Mektebi Alisi'ne ek olarak, Avusturyalı uzman Veith öncülüğünde başlatılan çalışmalarla 1915 yılında Hendek Orman Ameliyat Mektebi açılmıştır. Veith'in Hendek Fidanlığ 1 ve Tohumhanesi, Hendek Orman Amenajman Planı, Kastamonu-Bolu kesim ihalelerinin yapılması konularında da desteği bilinmektedir. Gerek Fransız uzman Tassy, gerek Alman Veith örneklerinde öne çıkan yabancı uzmanların, bir yandan ormancılık uygulamaları ile ilgilenirken diğer yandan ormancılık eğitimiyle ilgilenmek zorunda kaldıkları görülmektedir.

Osmanlı İmparatorluğunun 30 Ekim 1918 tarihinde Mondros Mütarekesini imzalamasiyla, gerek yabancı uzmanların sınır dışı edilmeleri gerekse ülkenin işgal edilmesi ormancılık çalışmalarını da duraklatmıştır. Ormancılık alanında yapılmaya çalışılan hukuki düzenlemeler bir anda boşta kalmış, Orman Mektebi Alisi Ders Nazırı Dr. Bauer tara- findan Ormancılık eğitiminde yapılmak istenen 1slahatlar kesintiye uğramıştır.

Orman Mektebi Alisi, İstanbul içerisinde çeşitli yer ve bina değiştirmiş, Balkan Savaşı ve Birinci Dünya Savaşı olayları nedeniyle defalarca sekteye uğramıştır (Eraslan, 1989).

Ormancılık eğitiminin yapılacağı yer, 1857 yılındaki kuruluşundan beri sürekli bir sorun olarak kendini göstermiştir. Eğitim, 1857 yılında Darphane binasında başlamış, bu binanın yanmasının ardından Adliye binasının bir kısmında devam etmiş, sonra Sultan Mahmut Türbesi karşısındaki Maruf binasında, ondan sonra da şimdiki Vefa Lisesinin yerinde bulunan Rüştü Mehmet Paşa konağında sürdürülmüştür. Bu mekândan sonra, Sultanahmet'te bulunan Maliye Nezâreti'nin içindeki tahsisli odalarda eğitim verilmeye çalışılmış ve ardından Halkalı Ziraat mektebine ve nihayet 1911 yılında Bahçeköy’e taşınılmıştır (İhsan, 1917). Orman Mektebi Alisi'ne Bahçeköy'de verilen yerleşke eski bir süvari karakolu veya kışlasıdır. Bugün İstanbul Üniversitesi Orman Fakültesi'nin bazı dershaneleri, konferans salonu ve kütüphanesinin bulunduğu Diker Binası, bu süvari kışlasının yerine inşa edilmiştir.

Ormancılık eğitimi savaşın getirdiği sosyal problemlerden de etkilenmiştir. Tehcir döneminde İstanbul, Sarıyer, Bahçeköy'den göç ettirilen azınlıklar, savaşın bitmesiyle birlikte köylerine geri dönmüş ve mağduriyetlerini bahane ederek köyde kargaşa çıkarmaya başlamış, en sonunda Orman Mektebi Alisi'ni ve öğrenci yurdunu talan etmeye kadar işi götürmüşlerdir. Daha vahim olayların yaşanmaması için işgal kuvvetlerinin baskısı ve İstanbul Valiliğinin emri üzerine okul zorunlu olarak boşaltılmıştır (Kutluk, 1965). Bahçeköy'deki yerleşke ise azınlıkların fiilen işgaline terk edilmiştir. Orman Mektebi Alisi, 1920 yılında Sarıyer İçmeler yolu üzerindeki Horozoğlu konağına ve az bir zaman sonra da, Yedi Sekiz Hasan Paşa konağına taşınmış (Kutluk, 1965) ve kira ödeyerek görevini icra edebilen bir kurum haline gelmiştir (Anonim, 1922).

Bu dönemde, aslında İstanbul hükümeti içinde bulunduğu sıkışık durum nedeniyle birçok alanda olduğu gibi, ormancılık konusunda da yapılması gerekenleri yapamaz hale gelmiştir. Sadece İstanbul civarındaki ormanların korunması, şehrin kereste ve odun ihtiyacının karşılanması ve orman yangınlarıyla mücadele gibi konularda kısıtlı işlemler yapılabilmiştir. Şüphesiz bu süreçte en çok sıkıntıyı, yerleşkesini kaybedip kiraya taşınmış olan orman mektebi yaşamıştır. Bu sıkıntıların doğal bir sonucu olarak öğrenci sayısı azalmış, ormancılık mes- 
leğine ilgi giderek zayıflamıştır. İstanbul hükümeti Orman Mektebi Alisi'ni Halkalı Ziraat Mektebi ile birleştirmenin yollarını arayarak ödenek ve yerleşke sorununa çözüm bulmaya çalışmıştır (Anonim, 1922). Bu durum Kurtuluş Savaşı yılları boyunca da devam etmiştir.

Kurtuluş Savaşı'nın kazanılıp Cumhuriyet döneminin başladığı yıllarda, ülkenin ormancılık yüksek öğrenimi yukarıda açıklandığı gibi, henüz yerleşim yeri sorununu dahi çözememiş bir durumdadır. İşte tam böyle bir zaman ve koşulda, Kurtuluş Savaşı'nın önemli şahsiyetlerinden Kazım Karabekir Paşa, 15 Kasım 1923 tarihinde, Sarıyer'de bulunan Yedi Sekiz Hasan Paşa konağındaki Orman Mektebi Alisi'ne bir ziyaret gerçekleştirmiştir (Tevhid-i Efkâr, 1923).

$\mathrm{Bu}$ makalenin amac1, Türkiye Cumhuriyeti tarihinin önemli şahsiyetlerinden Kazım Karabekir Paşa'nın çokça bilinen asker kişiliği, kimsesiz çocukları esirgeyen şahsiyeti yanında, ormanlarla ilgisini saptarken ormancılık eğitim öğretimi, orman devlet ve toplum ilişkileri konusunun anlaş1labilmesine katkı yapabilecek saptamalarla, olası tartışma konularını paylaşmaktır.

\section{Kazım Karabekir Paşa ve Orman Mektebi Alisi}

Kazım Karabekir Paşa 23 Temmuz 1882'de İstanbul'da doğmuştur. Baba mesleğini seçerek asker olmuş, 1902'de Harbiye Mektebi'ni, 1905'te Erkân1 Harbiye Mektebi'ni birincilikle bitirmiş ve kurmay yüzbaşı olmuştur. Kurmay stajını Manastır'da Üçüncü Ordu emrinde tamamlamış ve 1912'de binbaş1 rütbesiyle Balkan Savaşı'na katılmıştır. 1914'te yarbaylığa, 1915'te albaylığa, 1918'de mirlivalığa yükselmiştir. 2 Mart 1919'da Erzurum'daki 15. Kolordu Komutanlığına atanmış ve Milli Mücadele hareketine katılan ilk komutanlardan biri olmuştur. Erzurum Kongresinin düzenlenmesinde büyük emeği geçmiştir. Milli Mücadele hareketleri boyunca Edirne Milletvekili ve Doğu cephesi komutanı olarak görev yapmıştır. 1920'de, Ermenilerce işgal edilen toprakları almış ve korgeneral rütbesine yükseltilmiştir. Türkiye'nin ilk uluslararası anlaşmalarından Gümrü Antlaşması'nı imzalamıştır. Savaş sebebiyle ortada kalmış binlerce yetim çocuğu, kurduğu yurtlarda eğiterek onları tekrar hayata kazandırmıştır. 24 Kasım 1924’te Birinci Ordu Komutanlığından ayrılarak sadece milletvekili olarak çalışmayı tercih etmiştir. 17 Kasım 1924'te Terakkiperver Cumhuriyet Fırkası'nı kurmuş ve bu partinin genel başkanlığına seçilmiştir. Partisi kapatılmış ve İzmir suikastı girişimiyle ilişkilendirilerek İstiklal Mahkemesi’nde yargılanmışsa da, ilgisi görülmeyerek beraat etmiştir. 1939 yılına kadar, 12 yıl boyunca siyasetin dışında kalmış ve anılarını kitaplaştırmıştır. Ardından ara seçimde İstanbul milletvekili olarak meclise girmiş ve 1948 yılında TBMM başkanlığı görevindeyken, Ankara'da vefat etti (Karabekir, 2008). Verilen öz

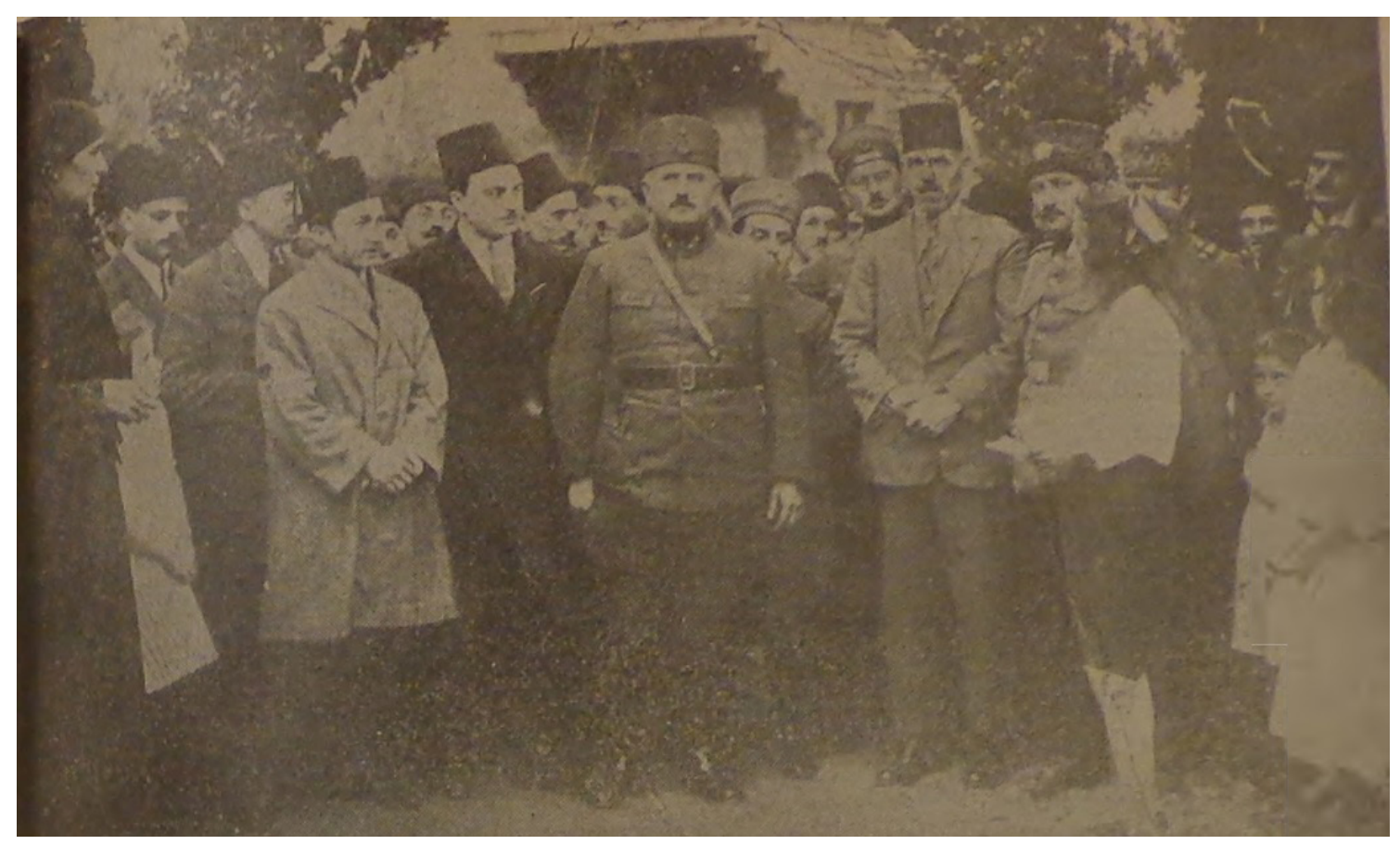

Şekil 1. Paşa karş1lanırken (Kaynak: Orman ve Av Dergisi, 1948-Say1 230)

Figure 1. Welcoming the Pasha (Source: Forest and Game Journal, 1948-Number: 230) 
yaşam öyküsünden de anlaşılacağı gibi, Orman Mektebi Alisi'ni ziyaret eden şahıs dönemin güçlü karakterlerinden biridir ve ormancilıkla ilgisinin ayrıntıları önemsenmelidir.
Kazım Karabekir Paşanın 15 Kasım 1923 tarihinde Sarıyer'de bulunan Orman Mektebi Alisi'ni ziyareti, dönemin günlük gazetelerinden Tevhid-i Efkâr'da haber olduğu gibi, Paşa'nın ölümü sebebiyle

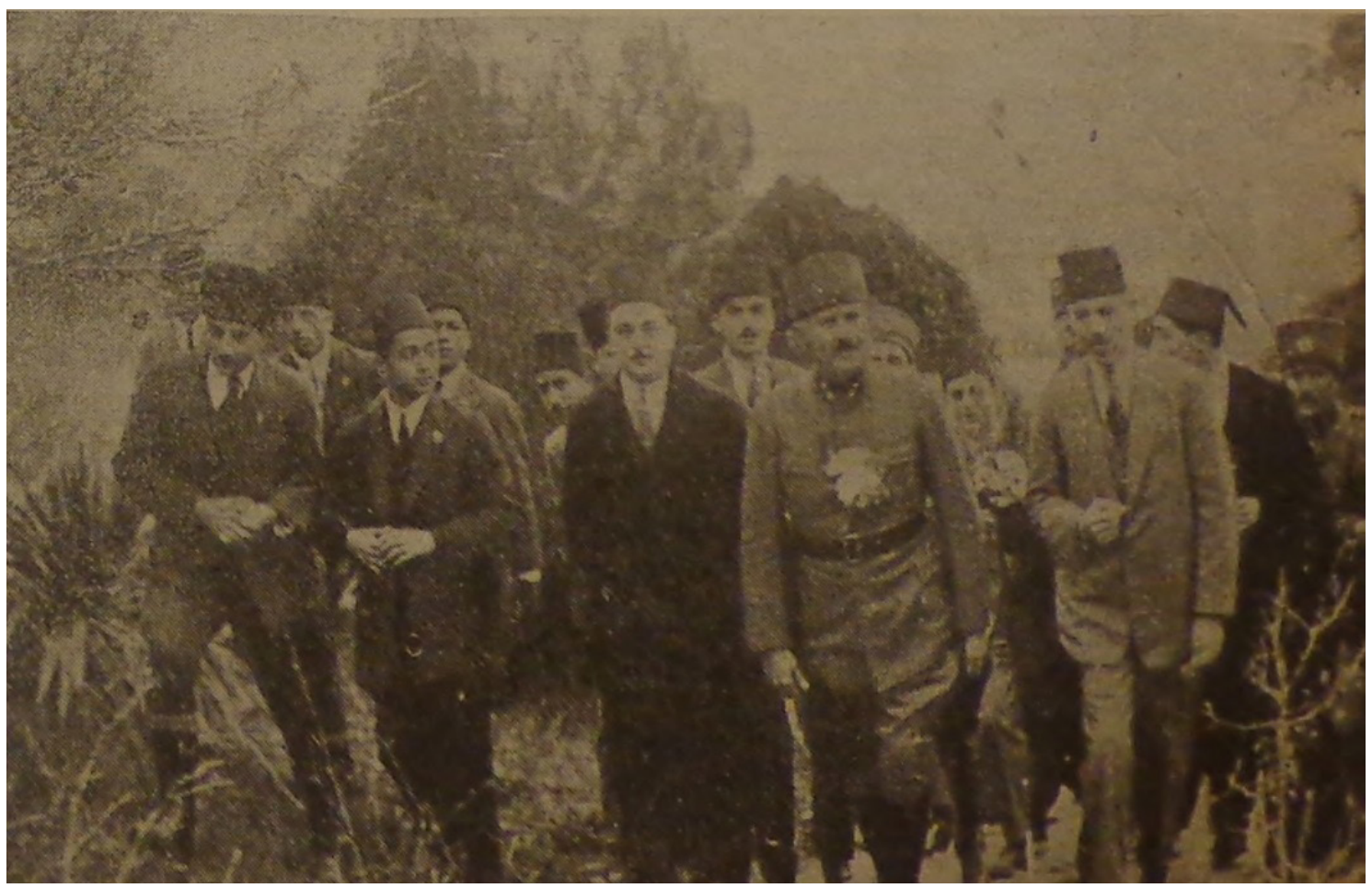

Şekil 2. Paşa okula çıarken (Kaynak: Orman ve Av Dergisi, 1948-Sayı 230)

Figure 2. Pasha leading towards the school (Source: Forest and Game Journal, 1948- Number 230)

Orman ve Av Dergisi'nde, 1948 y1lında yine haber yapılmıştır (Şekil 1). Fakat sonraki yıllarda bu ziyaret pek hatırlanmamış, paşanın sözleri üzerine hak ettiği kadar tartışmalar yürütülmemiştir.

Kazım Karabekir Paşa 15 Kasım 1923 günü saat on bir buçukta Sarıyer'e geldiğinde, halkın yaşa nidalarıyla karşılanır. Önceden hazırlanmış zafer takının altında, Süleyman Şah Kayaalp okulundan küçük bir kız öğrenci "İstiklal ordusunun fedakâr kumandanı, yetimler babası Kazım Karabekir Paşa hoş geldiniz" diyerek Paşa’ya çiçekler sunar (Şekil 1). Paşa bu küçük öğrencinin samimi sözlerine "gözlerinden öperim, bu memleketin yirmi sene sonra sahibi sizlersiniz” cevabını verir (Tevhid-Efkâr, 1923). Karabekir Paşa, takdim edilen çiçekleri, bir madalya gibi göğsüne takarak (Şekil 2) ve halkın arasından yürüyerek Hidayetin bağı üzerinde bulunan Yedi Sekiz Hasan Paşa konağındaki (Şekil 3) Orman Mektebi Alisi'ne ulaşır. Bugün bu konak, Sarıyer ilçesi Merkez Mahallesi, Gazi Hasan Paşa Sokak Numara 9'da, fakat sadece kalıntıları görülür halde bulunmaktadır. Orman Mektebi Alisi'nden izler görmek mümkün değildir.

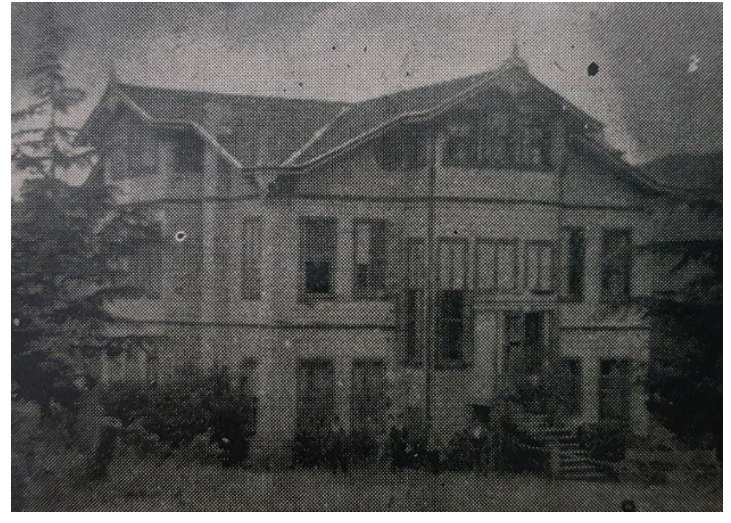

Şekil 3. Sarıer Yedi Sekiz Hasan Paşa Konağ1 (Kaynak: Orman ve Av Dergisi, 1965-Say1 7) Figure 3. Hasan Pasha Mansion at Sariyer (Soruce: Forest and Game Journal, 1965-Number 7)

Kisa bir dinlenme sonrasında, Orman Mektebi Alisi'nin Matematik öğretmeni Talat Bey bir konuşma yaparak Paşa'nın ormanlara verdiği destek ve katk1dan dolayı kendisine Fahri Müderrislik (Fahri Öğretmenlik-Doktora) unvanı verileceğini bildirir. Bunun üzerine Kazım Karabekir Paşa teşekkür ederek; 
"Meslektaşlarımla iftihar ederim. Ormanlar hakkında hissiyatımı arz edeyim. İnsanın bir iki ăgaca bakarken ruhundan gülümsememesi mümkün müdür? Öyle zannediyorum ki herkes aynı hisle mütehassistir. Fakat bütün bunlara rağmen öyle yerlerimiz, öyle memleketlerimiz var ki tek ăgaçtan bile mahrumdur. Ormansız memleket saçsız kız gibidir.

Arkadaşlar! Ormansız yerlerde toprak felâketi daimîdir. Ormanlar memleketlerin, beldelerin sthhat ve feyz kaynağıdır. Fakat sevgili arkadaşlarım, biz maalesef orman ilmini bilmiyoruz. Bunu halka anlatacak sizlersiniz. Bugün sizin aranızda bulunduğum için en şerefli dakikalarımı yaşlyorum. Arkadaşlar hepinizin gözlerinden öperim. Teklif ettiğiniz Fahri Müderrislik benim için ebedi bir şereftir” (Tevhid-i Efkâr, 1923) der.

Kazım Karabekir Paşanın konuşmasına "meslektaşlarımla iftihar ederim" şeklinde başlamasını, kendisini de bir ormancı olarak kabul etmekten duyduğu mutluluğun bir göstergesi olarak kabul et- mek gereklidir. Paşa, aldığı belgenin fahri, sembolik bir anlam ifade ettiğini bilen bir kişi olmasına rağmen, "meslektaşlarımla iftihar ederim" sözleri ile ormancılık camiasının bir parçası olarak kabul görmenin kendisini de mutlu ettiğini belirtmiş ve ormancılık mesleğini onurlandırmak istemiştir.

Kerime Nadir'in (1948) "Ormandan Yapraklar" romanında, ormancıların ülkenin pek çok yerine "Ormansız memleket saçsız kız gibidir" sözünü yazarak bir farkındalık oluşturmak istediği ifade edilmektedir. Ormancıların kullandığı bu sözün Kazım Karabekir'in okul ziyaretinde kullandı $\breve{g}_{1}$ veciz sözden mi, yoksa o günün Türkçesinde kullanılan bir deyimden mi kaynaklandığı bilinmemektedir.

Konuşmalar sonrasında, amenajman hocası Şekip Bey tarafından Paşa'ya teşekkür edilerek orijinal kopyası Kazım Karabekir Vakfi'nda halen korunan ve ilk defa bu makale ile yayımlanan, Fahri Müderrislik belgesi (Şekil 4) takdim edilmiştir.

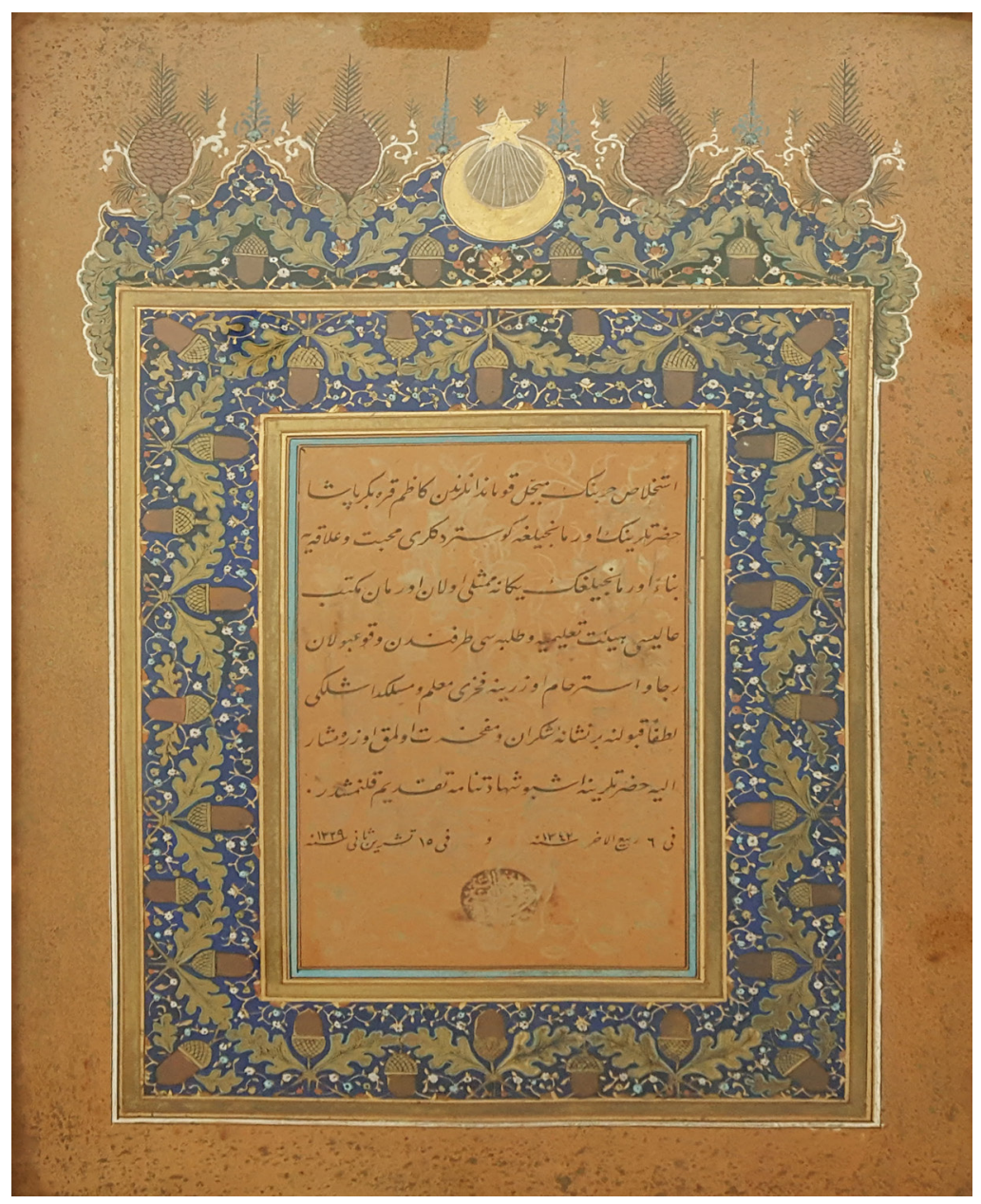

Şekil 4. Fahri Müderrislik Diploması - Şahadetname, (Kaynak: Karabekir Vakfi) Figure 4. Certificate of Honorary Professorship (Source: Karabekir Foundation) 
Şekil 4'te de görülebileceği gibi, ay yıldız ve hilalin her iki yanında çam kozalak ve ibreleri resmedilmişken belge metninin çevresi meşe palamut ve yapraklarıyla süslenmiştir. Bu süslemelerden de anlaşılacağ1 gibi, Karabekir Paşa için okula ve kişiye özel bir belge hazırlanmıştır ve ziyaretin bir tesadüf olmadığı, planlı bir gezi şeklinde gerçekleştiği görülmektedir.

Orman Mektebi Alisi Fahri Müderrislik belgesinin E. Kılıç tarafından günümüz Türkçesine çevrilmiş hali aşağıda verildiği gibidir.

İstihlâs harbinin mübeccel kumandanlarından Kazım Karabekir Paşa hazretlerinin ormancllı̆̆a gösterdikleri muhabbet ve alakaya binaen ormancilığın yegâne temsilcisi olan Orman Mektebi Alisi Heyeti Tâlimiye ve Talebesi tarafindan ortaya çıkan rica ve istirhâm üzerine Fahri Muallim ve meslektaşlığı lütfen kabulüne bir nişaneyi şükran ve mefharet olmak üzere müşârünileyh işbu şehadetnâme takdim kllınmıştır.

\section{Fi 6 Rabiülâhir 1342 - Fi 15 Teşrin-sani 1339 Mühür}

Orman Mektebi Alisi Müdüriyeti

Metnin dil uyumunu bozmamak için, çeviri sırasında, özgün terim ve tarihler korunmuştur. Ancak, bugün için anlaşılması zor olabilecek kelimelerden istihlâsın kurtuluş, mübeccelin saygın, heyeti talimiyenin akademik kurul, muallimin öğretmen, müşârünileyh teriminin adı geçen ve şehadetnâme kelimesinin diploma veya yazılı kanıt anlamına geldiğini belirtmek gereklidir.

Hazırlanan fahri müderrislik belgesinde, Orman Mektebi Alisi yöneticilerinin “ormancılığın yegâne temsilcisi olan" sözleriyle kendilerini ormancilığın tek temsilcisi olarak tanımlaması ilginçtir. $\mathrm{Bu}$ durum, ülkenin içinde bulunduğu koşullarda, ormancılık örgüt yapısının zayıflığından kaynaklanmış olabileceği gibi, Cumhuriyet yönetiminin Kastamonu'da açmayı planladığı ve nizamnamesi dahi hükümetçe hazırlanan (Anonim, 1921) fakat bir türlü açılamayan ikinci ormancılık okuluna gönderme yapmak maksadiyla da metne konmuş olabilir.

Fahri müderrislik belgesinin tarihi, hem hicri, hem Rumi olarak belirtilmiştir ve ziyaret tarihi ile aynı gün (15 Kasım 1923) olarak yazılmıştır. Bu da Paşa’nın ziyaretinin önceden planlanmış ve hazırlıklı bir ziyaret olduğunu kanıtlamaktadır.

Tören bittikten sonra Paşa, okulu gezerek incelemelerde bulunur. Öğrencilerle ilgilenir (Şekil 5). Tevhid-i Efkâr gazetesinin 16 Kasım 1923 tarihli sayısında yer alan haberden öğrendiğimize göre, bu öğrencilerden Saffet Efendi; memleketimizde ormancılığa önem verilmediğini ifade ederek bu hususta Paşa'dan yardım beklediklerini beyan eder.

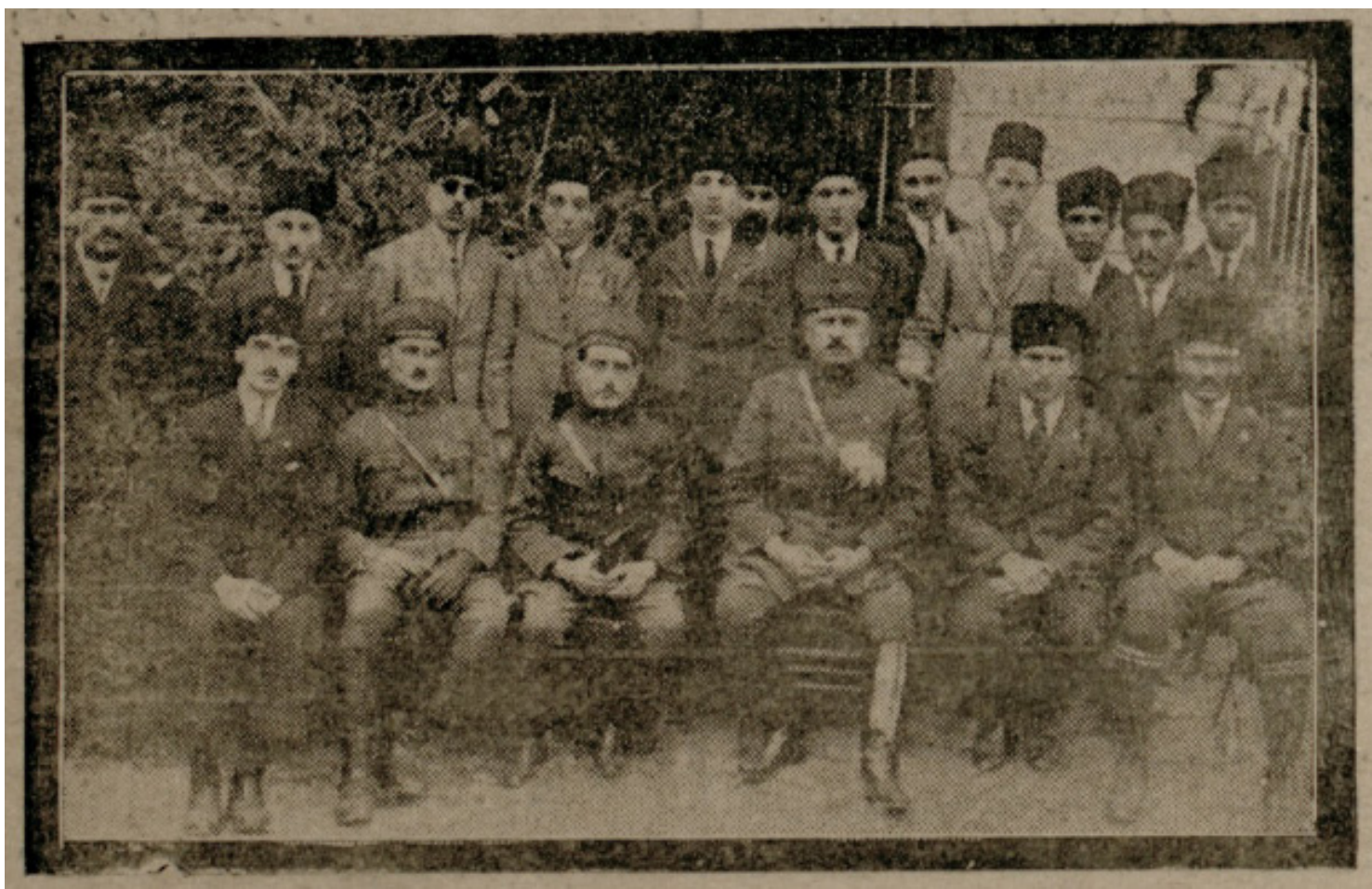

Şekil 5. Paşa son sınıf öğrencileriyle birlikte (Kaynak: Tehvid-i Efkar gazetesi, 16.11.1923)

Figure 5. Pasha together with senior class students (Source: Tevhid-i Efkar News, 16.11.1923) 
Kazım Karabekir Paşa'nın öğrenciye verdiği yanıt Tevhid-i Efkâr gazetesinin aynı sayısında bulunmaktadır. Osmanlıca metinden E. Kılıç tarafından yapılan çeviriye göre, Karabekir Paşa öğrencinin sözleri üzerine;

"Hür bir hava teneffüs ediyoruz. Size ilk defa işiteceğiniz bir cümle söylüyorum: Biz İstiklâl Harbini ormanlar sayesinde kazandlk. Bu bir muammadır (bilinmeyendir (Çn: Çevirenin notu). Daha bir zaman muamma olarak kalsin. Onu gelecek zaman halledecektir. Sulh (barış, Çn) olmuştur. Fakat iktisadî sahadaki harbe henüz yeni başlyyoruz. Bu sahada sulh ve mütareke yoktur. Mağlûbiyetin telafisi mümkün değildir. Siyasî harplerle ordu harplerindeki mağlûbiyeti iktisadî galibiyetler telâfi edebilirse de iktisadî mă̆lubiyetleri siyasî harpler telâfi edemez. İktisat sahasında mağlûp olan Türklerin ne elim anlar geçirdiğini hepimiz görüyoruz. 60-70 sene evvel ormanlarımı ilmî değilse de, halkımız gibi, tabî̀ bir şekilde mevcut idi. Hiç olmazsa maneviyatla muhafaza ediliyordu. İdareyi müstebide (baskıcı idare, Çn) garbı taklit edeceğiz diye, saf Türk halkındaki maneviyat, ananeleri, mukaddesatı aldı götürdü. Buna mukabil medeniyet getireceği yerde, füyüzatımızı (feyiz aldı̆̆ımı değerleri, Çn), ahlâkımızı ve servetimizi de mahvetti, kuruttu. Arkadaşlar! Memleketi iktisat sahasında yükseltmek Türklüğe ve Islamiyet'e has olan şiarımız ve imanla çalışmak hepimiz için borçtur. Her müşkülâta katlanarak yetişecek olan sizler vatanın ümidi, istikbalisiniz. Azim ve imanımızı kırmaksızın çalışın, arkadaşlar” diyerek düşüncelerini paylaşır.

Yukarıdaki sözlerden, Karabekir Paşanın silahlı mücadelenin kazanılmasını yeterli görmediği ve ekonomik bir savaş içerisine girildiğinin farkında olduğu, ormancılığı ekonomik savaşın önemli bir alanı olarak kabul ettiği anlaşılmaktadır.

Karabekir Paşa, okuldaki yemeğe de katılır (Şekil 6). Yemek sonrası takdim edilen mektebin hatıra defterine Paşa uzun ve açı bir yazı yazar. Paşa yazdığ1 yazıda özetle "Ben ăgaç gölgesini diğer sayeye (korunak, Çn) tercih ederim. Hem minnet de istemez" (Tevhid-i Efkâr, 1923) demiştir. Mektebin Hatıra defterinin bugün nerede olduğu, ne yazık ki, bilinmemektedir.

Paşa okulda yaklaşık dört saat kalmış ve öğleden sonra üç gibi Büyükdere halkının davetini kabul ederek okuldan ayrılmıştır. Şekil 7'den de görüldüğü gibi, karşılamada kendisine takdim edilen çiçekleri göğsüne takarak ve fahri öğretmenlik belgesini bizzat taşıyarak geziden duyduğu memnuniyet nişaneleriyle okuldan ayrılmıştır.

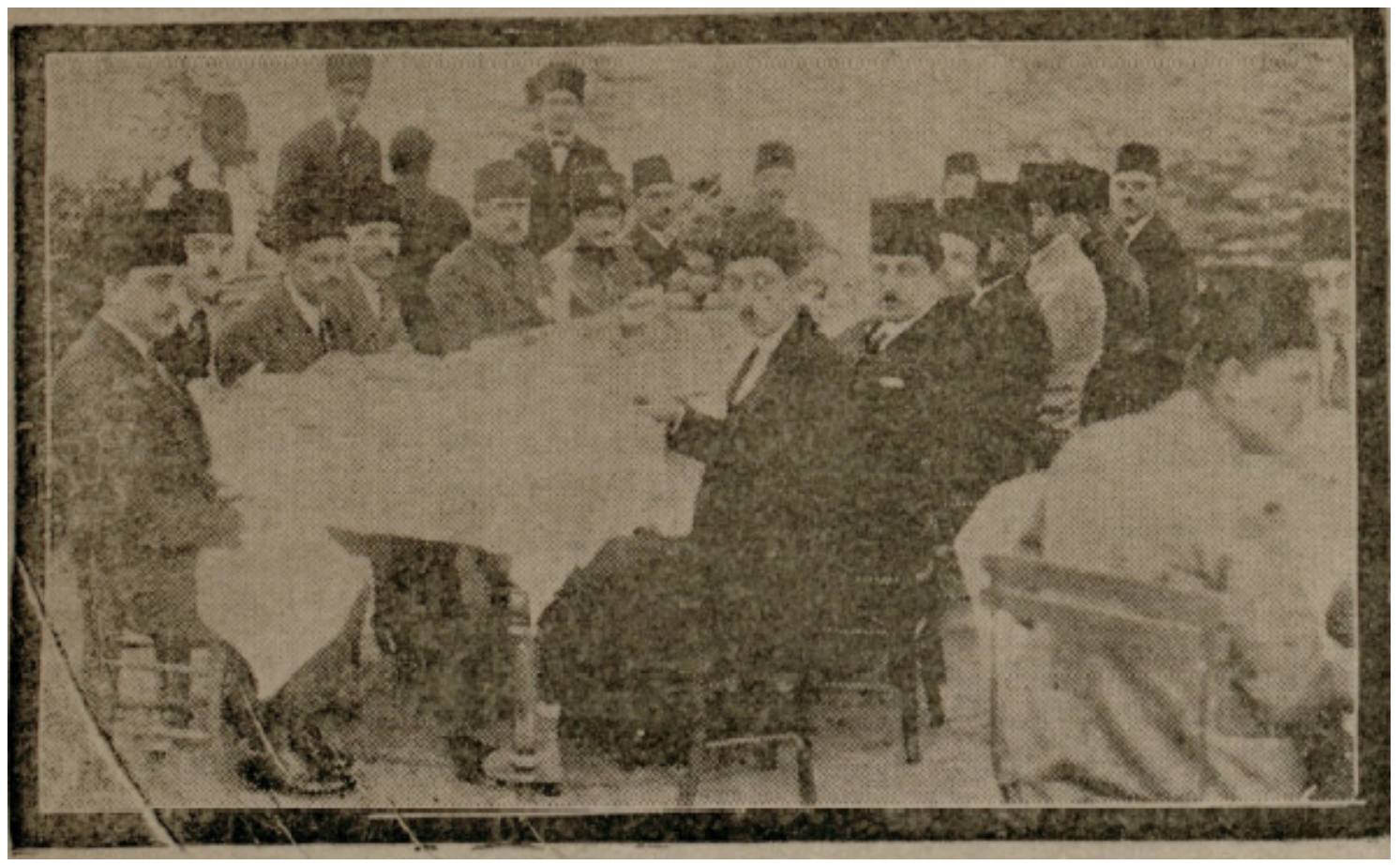

Şekil 6. Paşa Orman Mektebi Alisi’nde yemekte (Kaynak: Tehvid-i Efkâr gazetesi, 16.11.1923) Figure 6. Pasha at lunch in Forest School (Source: Tevhid-i Efkar News, 16.11.1923) 


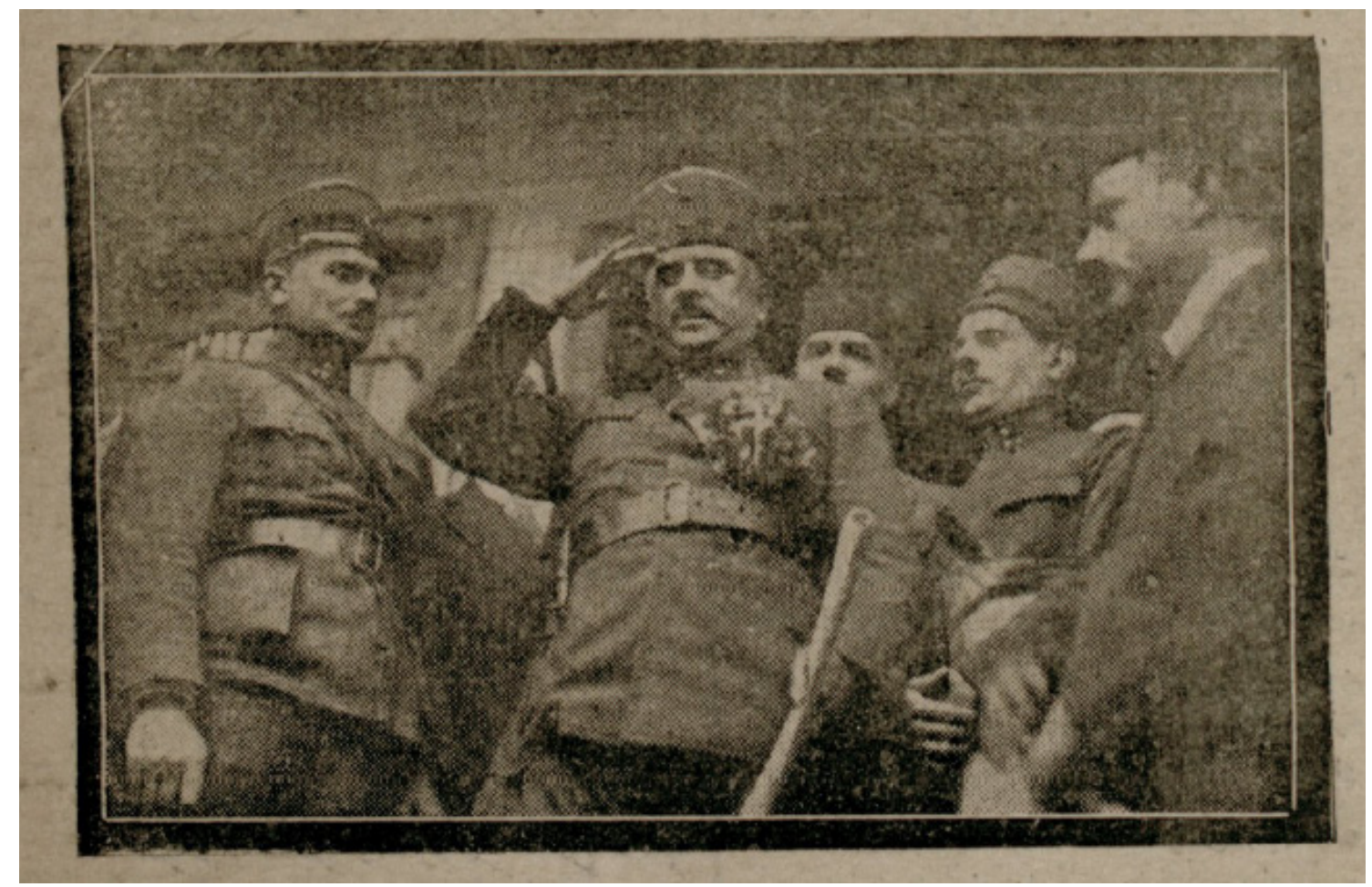

Şekil 7. Diploma ve Çiçekleriyle Paşa Orman Mektebinden ayrılırken (Kaynak: Tehvid-i Efkâr gazetesi, 16.11.1923)

Figure 7. Pasha leaving Forest School with his diploma and flowers (Source: Tevhid-i Efkar News, 16.11.1923)

\section{Karabekir'in Orman Mektebi Alisi gezisi sonrası gelişmeler üzerine tartışma}

Karabekir Paşa'nın ormancılık eğitimi ve okuluna ilgisi 15 Kasım'da yaptığı gezi ile sınırlı kalmamıştır. Orman Mektebi Alisi'nde yaptığı görüşmelerde öğrenci ve öğretim üyelerinin kendisine aktardı̆̆ önem verilme ve yer sorunlarından etkilenmiş olsa gerekir ki Kazım Karabekir Paşa, 7 Aralık 1923 tarihinde Edirne dönüşünde Kemerburgaz üzerinden Bahçeköy’e uğrar. Geçmişte Orman Mektebine tahsis edilmiş olan ve 1911-1920 yılları arasında eğitimin yapıldığı, tehcirden dönen azınlıkların yarattığ 1 sorunlar nedeniyle boşaltılan eski Süvari karakolunu veya Orman Okulu yerleşkesini yerinde görür. Fakat buranın fiziki şartlarını beğenmez ve okulun buraya tekrardan gelmesini uygun bulmaz (Karabekir, 2009).

Aslında bu dönemde kiracı olan Orman Mektebi Alisi için Ayazağa Çiftliği tahsis edilmek istenir. Bu isteğe, henüz halifelik kaldırılmadığı için halen yetki ve etki sahibi olan Halife Abdülmecid Efendi "çiftliğin babadan kalma yer olduğunu ve istirahat amaçli kullanma niyetini ileri sürerek" tahsisin yapılmamasını ister (Anonim, 1923). Bunun üzerine orman okulu için, Şehzade Yusuf İzzettin Efendi'ye ait olan ve saltanatın kaldırılmasıyla boşaltılan Zincirlikuyu köşkü gündeme gelir. Kara- bekir Paşa, belki de Orman Mektebi Alisi talebesi Saffet Efendinin, ziyaretinde söylediği sözlerini hatırlayarak bir yardımda bulunmak ister. Paşa, Adnan (Adıvar) Bey aracılığıyla Halife Abdülmecid Efendi'ye orman okulunun Zincirlikuyu Köşküne taşınma talebini iletir (Karabekir, 2009). Fakat Halife, yine benzer gerekçelerle, bu işe sıcak bakmaz.

Bu dönemde Ziraat Bakanlığ 1 da, Maliye Bakanlığ aracılığıyla Başbakanlığa bir yazı yazarak Zincirlikuyu Köşkünün orman okuluna tahsis edilmesini resmi olarak talep eder. Fakat Zincirlikuyu Köşkünün Dârü'l-eytam'a (Yetimler Yurdu) tahsis edileceği hususunda Atatürk'ün de imzasının bulunduğu bir kararname çıkarılır. Kararname ile Orman Mektebi için başka bir yer bakılması istenir (Anomim, 1924a).

Sarıyer'deki kiracılık sorununa çözüm olacak yeni bir okul alanı bulunamayınca, kamu maliyesine daha fazla ek kira yükü oluşturmamak üzere, Orman Mektebi Alisi 1924 tarihinde (Anonim, 1924b), yeniden ve mecburen Bahçeköy'deki eski yerleşkeye taşınmak durumunda kalır.

Orman Mektebi'nin Bahçeköy'deki yerleşkeye geri dönüşüyle ilgili doğrudan bir karar veya kaynağa ulaşılamamıştır. Bununla birlikte 04.06.1924 
tarihli Bakanlar Kurulu'nun Orman Mektebi'ne kamyonet alınmasıyla ilgili kararında, 1924'de Bahçeköy'e dönüşün gerçekleşmiş olduğu anlaşılmaktadır (Anonim, 1924b).

\section{Kurtuluș Savașını kazandıran ormanlarla ilgili sır üzerine tartışma}

Kazım Karabekir Paşa’nın 15 Kasım 1923 günlü Orman Mektebi Alisi ziyareti öncesinde de ormancılığa ilgisini kanıtlayan örnekler bulunmaktadır. Erzurum'da görev yaptığı dönemde civar illerde ağaç bayramları düzenlemiş (Şekil 8), ve kurdu- ğu yetimler mektebinde ziraat dersleri verdirmiştir. Bu nedenle, Paşa'nın ormancılık konusuyla ilk defa Orman Mektebi Alisi’ni ziyaretle tanıştığı veya ormanc1lık üzerinde daha öncesinde zihinsel bir uğraş içerisinde olmadığını söylemek güçtür. Nitekim Fahri Müderrislik belgesini aldıktan sonra yaptığı konuşmada, ormansız yerlerde yaşanan toprak sorunundan bir felaket olarak söz etmesi, ormanlarla beldelerin refahı arasında ilişki kurmas1, yurdun ormansız yerlerinin bulunmasını ve ormancılık bilimini bilmeyişimizi bir şikâyet konusu olarak dile getirmesi, ormanc1lık konusuna özel ilgisini kanıtlamaktadır.

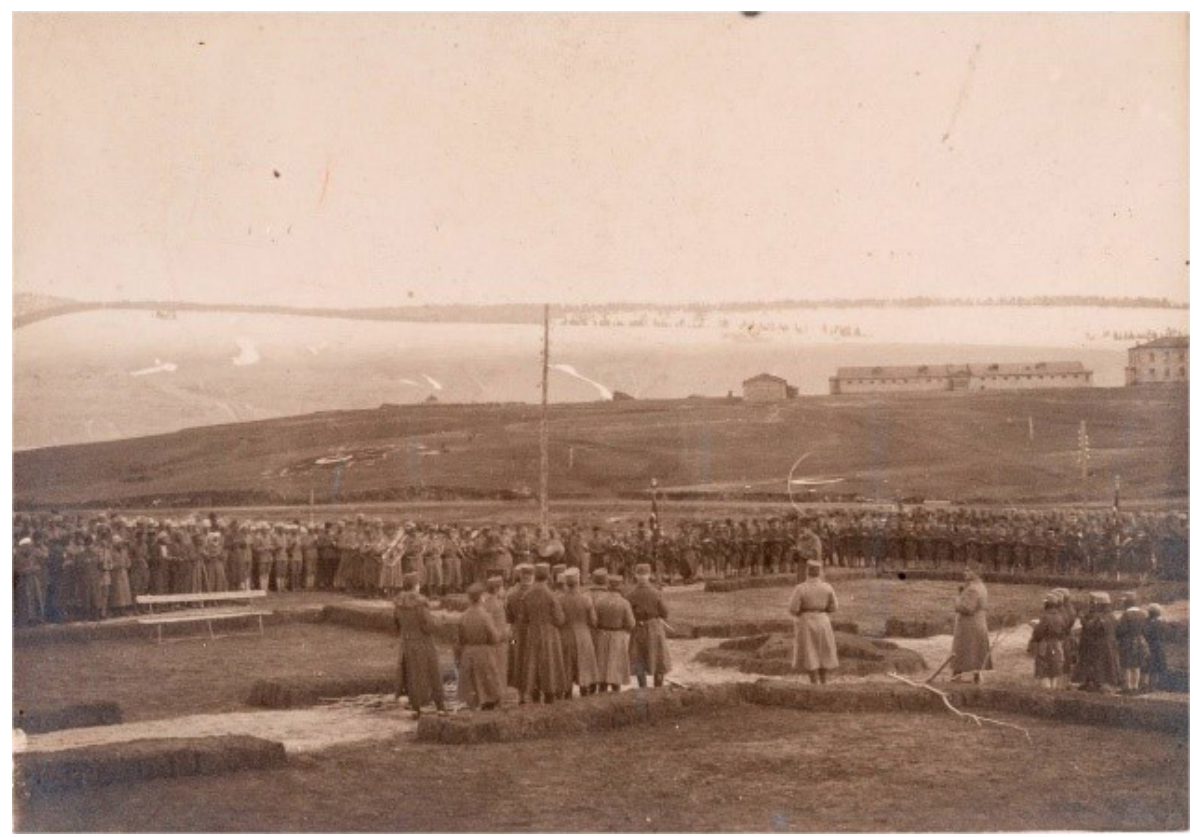

Şekil 8. Sarıkamış Ağaçlandırma Bayramı 23 Nisan 1922 (Kaynak: Karabekir Vakfı) Figure 8. Sarıkamış Afforestation Ceremony on April 23 ${ }^{\text {th }}$, 1922. (Source: Karabekir Foundation)

Karabekir Paşa’nın Orman Mektebi Alisi’nde yaptığı konuşmadaki "Arkadaşlar! Memleketi iktisat sahasında yükseltmek Türklüğe ve İslamiyet'e has olan şiarımız ve imanla çalışmak hepimiz için borçtur" ifadesi, ormanlardan ve ormancılardan iktisadi bir katkı beklediğini kanıtlamaktadır. Ancak aynı ziyarette kullandığ 1 "Arkadaşlar! Ormansız yerlerde toprak felâketi daimîdir. Ormanlar memleketlerin, beldelerin sihhat ve feyz kaynağıdır" sözleri, orman varlığının odun üretimi dışındaki işlevlerinin de Paşa tarafından doğru algılandığını göstermektedir. Bugün için çok özel bir farkındalık olarak görülemeyebilecek bu bilinç düzeyi, 1923 dünyası ve Türkiye'si için ve özellikle ormancı olmayan biri için, dikkate alınması gereken önemli bir farkındalık kanıtıdır.

Bununla birlikte, Paşa'nın konuşmasında geçen "Biz İstiklâl Harbini ormanlar sayesinde kazandık.
Bu bir muammadır. Daha bir zaman muamma olarak kalsın. Onu gelecek zaman halledecektir" ifadesi, üzerinde durulması gereken sözlerdir ve $\mathrm{Pa}$ şa'nın ormancılık konusundaki ilgisi ve birikimine ilişkin daha fazla bilgiler barındırdığ 1 kesindir. Ne yazık ki bu konu ormancılık kamuoyunda ve tarihçiler arasında yeterince tartışılmamış ve söz edilen muammayı geçmiş zaman halledememiştir.

Karabekir Paşa'nın bir sır olarak ifade ettiği ormanların kurutuluş savaşının kazanılmasına yaptığ1 katkıyı anlayabilmek için Atatürk'ün Samsun'a çıktığı 19 Mayıs 1919 tarihi ile Türkiye Büyük Millet Meclisi tarafından Cumhuriyet'in ilan edildiği 29 Ekim 1923 tarihleri arasını dikkatli incelemek gerekir. Atatürk, 1919 yılında Kazım Karabekir Paşa'ya gönderdiği telgrafta "Siyasi zümrelerin şimdiye kadar menfaatleri uğrunda halkı baziçe (oyuncak, Çn) etmiş olmaları, ahalide 
her türlü teşkilâta karşı bir nevi ihtirazkârlık tevlid eylemiştir (çekingenlik doğurmuştur, Çn)" (Karabekir, 1960) demektedir. Bu telgraf ile Karabekir Paşa'nın yukarıda verilen konuşmasında geçen "60-70 sene evvel ormanlarımız ilmî değilse de, halkımız gibi, tabiî bir şekilde mevcut idi. Hiç olmazsa maneviyatla muhafaza ediliyordu" sözlerini birlikte değerlendirmek gereklidir. Osmanlı'nın Arazi ve Orman Nizamnameleri ile yeni kurallar ve kurumlar oluşturmasının, gerek Atatürk'ün söz ettiği halkın güven kaybına, gerek Karabekir'in belirttiği "muhafaza edilen" ormanların korunamamasiyla bir ilgisinin olması gereklidir.

Aslında, Osmanlı döneminde de ormancılık alanında yapılan yeniliklerin halkta ve devlet yönetiminde yarattığ 1 güvensizlik bilinen bir gerçekti. Örneğin 28 Mart 1917 tarihinde Ormanların Usulü İdare-i Fenniye Kanunu mecliste görüşülmeye başlandığında, kanun tasarısında geçen koru ve baltalık terimleri, milletvekilleri tarafından da "köylülerin yararlandığı baltalık" olarak algılanmış ve yeni bir kısıtlama getiriliyor diye tepkiyle karşılanmıştır (Anonim, 1917).

Hatta Orman Umum Müdürü Tevfik Bey’in II. Islahat raporundan öğrendiğimize göre, "başlangıçta her köyün ihtiyacına göre baltalık tefrik ve tahsis edilmek istenmiş" fakat bu düşünce yerine getirilmeyerek "sırf köy ahalisinin ormandan faydalanmasını kolaylaştırmak için, belirli bir bedelle 50 ağaca kadar ilansız yararlanma izni verilmiş ve müthiş suiistimallere yol açılarak hazinenin gelir kaybına neden olunmuştur (Kutluk, 1967).

Bir Osmanlı aydını ve sorumlu devlet adamı olarak, Atatürk ve Karabekir Paşa'nın veya yakın çevrelerinin bu konuları takip etmedikleri veya halk ile ilişkisini kuramadıklarını söylemek mümkün değildir. Nitekim Cumhuriyet döneminde, halkın ormanlardan yararlanma biçimiyle ilgili geçmişten gelen sorunları çözebilmek için Büyük Millet Meclisi ve hükümetleri ormanla ilgili kanun çalışması yapmış ve üç oturum sonucunda gizli oylama ile 11 Ekim 1920 tarihinde Baltalık Kanununu çıkarmıştır (Ceride-i Resmiye, 1921). Bu kanunun çıkarıldığı tarih ile Kurtuluş Savaşının önemli dönüm noktalarını karşılaştırmalı olarak incelemek, daha doğru yorumlar için gereklidir. Baltalık Kanunu çıktığında TBMM'nin açılışının üzerinden daha beş ay geçmiştir. Halkın yeni meclisi ve yönetim düzenini benimseyip benimsemeyeceği henüz net değildir. Milli mücadelenin varl1ğını halka kabul ettirme kaygılarının taşındığ 1 bir döneminde Baltalık Kanunu kabul edilmiştir.

Dokuz maddeden ibaret olan Baltalık Kanunu, her ne kadar Ekim ayında mecliste oylanmış olsa da, ancak bir sene sonra 7 Mart 1921 tarihinde resmi gazetede yayımlanarak yürürlüğe girmiştir. Kanun yürürlüğe girdiğinde henüz sadece I. İnönü Savaş1 (6-10 Ocak 1921) kazanılmıştır.

Baltalık kanununda odunculuk, kömürcülük ve kerestecilik ile uğraşan veya azami $20 \mathrm{~km}$ mesafe ile büyük ormanlara komşu olan ve ormanla ilişkisi bulunan köylerdeki her haneye azami 18 dönüm orman verileceği, bu yerlerin korunmasından ise, ihtiyar heyetinin gözetiminde köy halkının sorumlu olacağı belirtilmektedir. Vakıf ormanları genel olarak bu düzenlemeden muaf tutulmuştur. Köylülere dağıtılacak devlet ormanı bulunmaması halinde ise özel ormanların, takdir edilecek bedel köylüler tarafından peşin olarak veya Ziraat Bankasına taksitle ödenmek şartıyla dağıtıma konu edileceği beyan edilmiştir. Köylülerce bu yerlerden üretilecek, yapacak ve yakacak odunların pazar yerlerinde satılması durumunda, vergi alınmayacağ1 gibi, belirlenecek günlerde köylerin imarı ve köy sandığına kaynak sağlamak için satış yapma hakkı verilmiştir.

Mecliste müzakere edilme aşamasında, çıkarılacak Baltalık Kanunu sayesinde dağıtım dışında kalacak çok büyük alanların insan ve hayvan girişlerinin yasak olacağ 1 için doğal olarak korunmuş olacağ1 iddia edilmiştir (Anonim, 1920)

Görüldüğü gibi, Kurtuluş Savaşını yöneten kurmay heyetinin, Osmanlı'da yaşanan orman halk çatışmasını değerlendirmek istediği ortadadır. Hiç şüphesiz uzun yıllar devam eden savaşlar nedeniyle psikolojik ve ekonomik olarak tükenmiş halkı, yeni bir Kurtuluş Savaşı için yeniden motive etmek üzere ormanlardan yararlanma üstünlükleri sunulmak istenmiştir.

Bununla birlikte Baltalık Kanununun dışında resmi kurumların, askeriyenin ve halkın ihtiyacı olan yakacak odunun tarife bedeli ile satılması, savaşta evi yıkılan halka ücretsiz kereste verilmesi ve yine savaş, isyan ve afetler sebebiyle tamir gereken yapılar için ücretsiz kereste verilmesi için üç farklı kanun daha çıkarılmıştı (Bingöl, 1990).

Nitekim Diker (1947) de Kurtuluş Savaşını yönetenlerin "ülkenin dış düşmanlarına karşı bir ölüm kalım savaşı verdiği esnada, içerde orman-insan ilişkilerinin doğurduğu şikâyet ve huzursuzluklara son vererek savaşa milletçe katılmayı sağlamak amacıyla Baltalık Kanununun çıkarıldığı” kanaatindedir. Bu düşünceyi daha sonra Cin'in (1978) de paylaştığ1 görülmektedir. Bununla birlikte, 39 sayılı Baltalık Kanunuyla ormana 20 km mesafedeki her haneye 18 dönüm orman verilmesi ormanlarda büyük tahribatlara neden olmuştur. 
Bu nedenle, Kazım Paşa'nın Kurtuluş Savaşının kazanılmasında ormanların bilinmeyen katkısını, 39 sayılı Baltalık Kanununda aramak olanaklıdır. Bunun yanı sıra Karabekir Paşa'nın “onu gelecek zaman halledecek" söylemi ile neyi kastettiği üzerinde de durmak gereklidir.

Kazım Karabekir'in Orman Mektebi Alisi’ni ziyaretinden sadece 5 ay sonra, 15 Nisan 1924 tarihinde 484 Sayılı "Devlet Ormanlarından Köylülerin İntifa Hakkına Dair Kanun” kabul edilmiştir. Aynı yıl bir de "Orman Talimatnamesi” çıkartılmıştır. Ayrıca, 504 Sayılı “Türkiye'de Mevcut Bilumum Ormanların Fenni Usulü İdare ve İşletilmesi Hakkında Kanun” kabul edilmiştir. Başka bir deyişle, ülkenin orman kaynaklarının vatanın kurtuluşu için yeteri kadar istismar edildiği ve buna artık bir son verilmesi gerektiği görülmüş ve milli mücadelenin başında kabul edilen 39 Sayılı Kanun, bağımsızlığın kazanılmasıyla birlikte ortadan kaldırılmıştır. Karabekir'in ifadesiyle "onu zaman halletmiştir".

\section{Sonuç}

Kazım Karabekir Paşa'nın 15 Kasım 1923 günü Orman Mektebi Alisi'ne yaptığı ziyaret ile ilgili belgelerden ve yaptığı konuşmalardan aşağıdaki sonuçları çıkarmak mümkündür.

Kazım Karabekir'i Kurtuluş Savaşında kanıtladığ1 asker kişiliği ve kimsesiz çocuklara sahip çıkan himayeci şahsiyetiyle hatırlamak yeterli değildir. Karabekir Paşa bir orman dostu olarak da hatırlanmalı, ülkedeki ormancılık eğitimine verdiği destekle, orman-toplum ilişkileri konusundaki güçlü farkındalığıyla da bilinmelidir.

Ormancılık eğitim ve öğretiminin, ne kurumsal yapı ne de yerleşim yeri açısından istikrarlı bir yapıya kavuşamadığı bir dönemde, Orman Mektebi Alisi'nin bugün üniversitelerin uyguladığ 1 "fahri doktora" kavramına hâkim olduğu gözlenmektedir. Bunun yanı sıra el yapımı ve kişiye özel belgeler düzenleyebilecek ve iyi organize edilmiş ziyaretlerle kendisine devlet düzeni içerisinde yer açabilecek bir çaba ve kültüre sahip olduğu görülmektedir. Karabekir Paşa'ya verilen belgede Orman Mektebi Alisi'nin kendini "ormancılığın tek temsilcisi” olarak tanımlaması ülke ormancılığında önemli bir misyon üstlenme isteğinin ve farkındalığının kanitidir.

Kurtuluş Savaşı sırasında ormanlarımız, resmi ve askeri ihtiyaçların karşılanması ile birlikte halkın yapacak ve yakacak odun ihtiyacını sağlanmas1 açısından son derece faydalı olmuştur. Aslında Meclis, ormanla ilgili çıkarmış olduğu kanunlar- la halkın yanında olduğunu göstermiş ve böylece kendi meşruiyetini de sağlamlaştırmıştır. Kurtuluş Savaşı için halkın daha güçlü olması gerektiğini bilen Ankara Hükümeti, ormanlarla halkına az da olsa iş ve aş imkânı sağlamış ve topyekûn savaş için ileride çıkaracağı Tekâlif-i Milliye kanunlarına zemin hazırlamıştır. Bir başka deyişle, Cumhuriyet dönemiyle birlikte, savaşta ve barışta ormantoplum ilişkisi görülmüş ve bu ilişki düzenlenmeye çalışılmıştır.

\section{Teşekkür}

Karabekir Vakfı kaynaklarını araştırmamıza açan, bu makalede yayınlanan belgelerin özgün örneklerine erişme ve yayımlama fırsatı veren Kazım Karabekir'in kızı Sayın Timsal KARABEKİR'e teşekkür ederiz.

\section{Kaynaklar}

Anonim., 1917. Meclisi Mebusan Zabit Ceridesi, Ticaret ve Ziraat Nezaret Bütçesi Tutanakları.

Anomim., 1920. Zabit Ceridesi, 1920. 78. Oturum Baltal1k Kanun Lahiyâsı görüşmeleri

Anonim., 1921. TC Başbakanlık Devlet Arşivleri Genel Müdürlüğü Cumhuriyet Arşivi Bölümü. 30.18.1.1/2.40.13.1.

Anonim., 1922. TC Başbakanlık Devlet Arşivleri Genel Müdürlüğü Osmanlı Arşivi. Meclis-i Vükela Mazbatalar1. Fon Kodu: 224.137.4.1 İstanbul.

Anonim., 1923. TC Başbakanlık Devlet Arşivleri Genel Müdürlüğü Osmanlı Arşivi. Hariciye Nezâreti İstanbul Murahhaslığ1. Fon Kodu: 21.149.1.1 İstanbul.

Anomim., 1924a. TC Başbakanlık Devlet Arşivleri Genel Müdürlüğü Cumhuriyet Arşivi Bölümü. 30.18.1.1 / 9.26.19.

Anomim., 1924b. TC Başbakanlık Devlet Arşivleri Genel Müdürlüğü Cumhuriyet Arşivi Bölümü. 30.18.1.1 /10.28.19.1.

Anomim., 1948. Genaral Kazım Karabekir. Orman ve Av Dergisi, Say1 230, Sayfa 28-29.

Atay, İ., 1975. Türkiye'de Akademik Düzeyde Ormancılık Eğitimi, İÜ Orman Fakültesi Dergisi, Seri A, Cilt XXIV, Say1 2.

Bingöl, İ., 1990. Geçmişten Günümüze Ormanlarımız ve Ormancılı̆̆ımız. Ormancılık Eğitim ve Kültür Vakfı, İstanbul.

Cin, H., 1978. Tanzimat'tan Sonra Türkiye'de Ormanların Hukuki Rejimi, Ankara Üniversitesi Hukuk Fakültesi Dergisi, Say1: 1Cilt:35

Ceride-i Resmiye., 1921. Baltalık Kanunu. No: 39 
Diker, M., 1947. Türkiye'de Ormancıllk. Orman Genel Müdürlüğü, Ankara.

Eraslan, İ., 1989: Türkiye'de ormancılık Öğretim ve Eğitim Kurumlarının Tarihsel Gelişimi, Ormancılık Eğitim Kültür Vakfi Yayın No 1., 157 sayfa.

Gümüş, C., 2012. Türkiye'de Ormancılık Eğitiminin Tarihsel Gelişimi, 5531 Sayılı Kanunun Yüksek Öğretim ve Eğitime Yansımalarının İrdelenmesi ve Hedefler Kongresi,

İhsan. 1917. Ormanlarımızın Tarihçesi. Orman Mektebi Alisi Mecmuası (1), 26.

Karabekir, K., 1960. İstiklâl Harbimiz. Türkiye Yayınevi, İstanbul.
Karabekir, K., 2008. Hayatım. Yapı Kredi Yayınları, İstanbul.

Karabekir, K., 2009. Günlükler. Yapı Kredi Yayınları, İstanbul.

Kutluk, H., 1965. Dağvaryan Efendi, Uyan ve Başını Kaldır. Orman ve Av Dergisi, Cilt 37 Say1 7, Sayfa 17-22,

Kutluk, H., 1967. Türkiye Ormancıllı̆̆ İle İlgili Tarihi Vesikalar Cild 2. Orman Genel Müdürlüğü, Ankara.

Nadir K., 1948, Ormandan Yapraklar. İnkılap Yayınevi, İstanbul.

Tevhid-i Efkâr, (1923). Tevhid-i Efkâr Gazetesi, 16 Kasim 1923 sayis1. 